\title{
PERLINDUNGAN HUKUM TERHADAP PEKERJA KONTRAK DALAM HAL PEMENUHAN JAMINAN KESEHATAN DAN KESELAMATAN KERJA DI DINAS LINGKUNGAN HIDUP DAN KEBERSIHAN KOTA DENPASAR
}

I Gede Bayu Mustikayana

Dr. I Wayan Wiryawan. SH.,MH

Program Hukum Bisnis Fakultas Hukum Universitas Udayana

\begin{abstract}
ABSTRAK
Perlindungan hukum terhadap pekerja kontrak dalam pemenuhan jaminan kesehatan dan keselamatan kerja di Dinas lingkungan Hidup dan Kebersihan Kota Denpasar telah mengacu pada peraturan perundang-undangan yang berlaku, namuan dalam penerapannya ada beberapa permasalahan sehingga pelaksanaan tidak berjalan dengan normal. Adapun permasalahannya adalah Bagaimanakah pelaksanaan perlindungan hukum terhadap pekerja kontrak dalam pemenuhan jaminan kesehatan dan keselamatan kerja oleh Dinas Linkungan Hidup dan Kebersihan Kota Denpasar ? dan Faktor-faktor apakah yang dapat menghambat pemenuhan hak kesehatan dan keselamatan kerja di Dinas Lingkungan Hidup Dan Kebersihan Kota Denpasar ? dengan menggunakan metode penelitian emperis yaitu melakukan pemelitian lapangan dan ditunjang dengan beberapa bahan hukum berupa peraturan perundang-undangan. Pelaksanaan jaminan keselamatan dan kesehatan kerja pekerja kontrak dimaksudkan untuk menjamin hak-hak dasar pekerja/buruh dan menjamin kesamaan kesempatan serta perlakuan tanpa adanya diskriminasi atas dasar apapun melalui pembinaan, peningkatan, penanggulangan keselamatan dan kesehatan kerja yang dilakukan dengan memberikan pelindung kepala, pelindung mata dan muka, pelindung telinga, pelindung pernapasan beserta perlengkapannya, pelindung tangan; dan/atau pelindung kaki dengan pola mendaftarkan dan memberikan kartu BPJS ketenagakerjaan, Faktor penghambat pelaksanaan pemenuhan jaminan keselamatan dan kesehatan kerja kepada pekerja kontrak dikarenakan adanya tindakan tidak aman yang dilatarbelakangi oleh adanya tindakan berbahaya dari pekerja bisa terjadi karena kurangnya pengetahuan dan ketrampilan kerja, kurangnya menguasai atau belum trampil dengan peralatan atau mesin baru dan faktor alamiah
\end{abstract}

Kata Kunci : perlindungan ; pekerja kontrak ; jaminan kesehatan dan keselamatan kerja

ABSTRACT 
Legal protection for contracted workers in fulfillment health insurance and work safety at environmental service and sanitary agency of Denpasar City have referred to applicable legislation. However, there are some matters in its application which caused its application not running smoothly. Those matters are how is legal protection for contracted workers being applied in fulfillment health insurance and work safety at environmental service and sanitary agency of Denpasar City? And what are some factors that can hamper the fulfillment of health and safety rights at environmental service and sanitary agency of Denpasar City? By implementing empirical research method namely conducting field research and supported by several legal materials in the form of statutory regulations. The implementation of work safety and health insurance for under-contracted workers is aimed at guaranteeing basic rights of labor/workers as well as guaranteeing equality of opportunity and treatment without discrimination on any basis through couching, improving, fostering, safety and health work by giving head protection, eyes and face protection, ears protection, breathing protection and its equipment, hand and feet protection by registering and providing employment BPJS cards, the factors that can hamper the fulfillment of health and safety rights at environmental service and sanitary for the workers are caused by unsafe action which comes from dangerous actions from the labor/workers that can be caused from lack of knowledge and skill, have not mastered or skilled the equipment or new machine and natural factors.

\section{PENDAHULUAN}

\subsection{Latar belakang}

Undang-Undang Nomor 13 Tahun 2003 tentang Ketenagakerjaan (selanjutnya disebut UU Ketenagakerjaan), dalam undang-undang ini hubungan kerja dibedakan menjadi 3 (tiga) yaitu hubungan kerja tetap, hubungan kerja kontrak dan hubungan kerja melalui pihak ketiga. Hubungan kerja tetap didasari oleh perjanjian kerja waktu Tidak Tertentu (selanjutnya disebut PKWTT) dan mensyaratkan adanya masa percobaan selama 3 (tiga) bulan (Pasal 56 dan Pasal 60 UU Ketenagakerjaan). Sedangkan hubungan kerja kontrak didasari oleh perjanjian kerja waktu tertentu (selanjutnya di sebut PKWT) dan tidak boleh mensyaratkan adanya masa percobaan selama 3 (tiga) bulan 
(Pasal 56 dan Pasal 58 UU Ketenagakerjaan). Sementara itu hubungan kerja melalui pihak ketiga didasarkan pada ketentuan Pasal 64 UU Ketenagakerjaan yang menyebutkan bahwa Perusahaan dapat menyerahkan sebagian pelaksanaan pekerjaan kepada perusaahaan lainya melalui perjanjian pemborongan pekerjaan atau penyediaan jasa pekerjaan yang dibuat secara tertulis.

Dalam Pasal 3 hurup b Undang-undang Nomor 1 Tahun 1970 tentang keselamatan kerja (selanjutnya disebut UU No. 1 Tahun 1970) menyatakan bahwa untuk dapat diberikan keselamatan kerja harus memenuhi persyaratan. ${ }^{1}$ Tugas pekerja kontrak pada Dinas Lingkungan Hidup Dan Kebersihan Kota Denpasar adalah pencegah dan penanggulangi sampah agar tidak menumpuk dan menyebabkan penyakit. Tugas ini merupakan tanggung jawab pekerja kontrak yang sangat beresiko jika di bandingkan dengan ketentuan pada Pasal 86 ayat (1) UU Ketenagakerjaan yang menyatakan bahwa setiap pekerja mempunyai hak untuk memperoleh perlindungan atas keselamatan dan kesehatan kerja untuk melindungi keselamtan pekerja guna mewujudkan produktivitas kerja yang optimal di selenggarakan upaya keselamatan dan kesehatan kerja. Selanjutnya diatur juga mengenai sistem keselamatan dan kesehatan kerja yang mewajibkan setiap perusahaan wajib menerapkan sistem manajemen perusahaan sebagaimana disebutkan dalam Pasal 87 UU Ketenagakerjaan yang mewajibkan perusahaan untuk menjamin keselamatan dan kesehatan kerja seperti yang di uraikan di atas merupakan bentuk perlindungan terhadap tenaga kerja. ${ }^{2}$

3-4.

${ }^{1}$ Indrajit dan Djokopranoto, 2006, Proses Bisnis: Outsourcing, PT. Grasindo, Jakarta, hal.

${ }^{2}$ N.L.M. Mahendrawati, 2009, “Perjanjian Outsourcing Dalam Kegiatan Bisnis”, Kertha Wicaksana, Vol.15. No 2, hal. 151 URL: https://docobook.com/perlindungan-hukum-terhadaptenaga-kerja-outsourcing-ojs-unu.html diakses pada 3 Januari 2018. 
Bagi pekerja kontrak di Dinas Lingkungan Hidup Dan Kebersihan Kota Denpasar saat melaksanakan tugasnya sangatlah berisiko terjangkit penyakit, yang ditulari dari sampah-sampah masyarakat, yang kemungkinan telah terjangkit penyakit yang menyebabkan pekerja kontrak tersebut menjadi mudah terjangkit penyakit. Sehingga peranan pemerintah harus memperhatikan pekerja kontrak agar mendapatkan jaminan kesehatan dan memberikan upah yang layak dengan pekerjaan yang berisiko bagi pegawai kontrak tersebut sebagaimana ketentuan pada Pasal 86 ayat (1) dan Pasal 87 UU Ketenagakerjaan.

\subsection{Rumusan Masalah}

Berdasarkan latar belakang masalah yang dikemukakan di atas maka dapat dirumuskan masalah sebagai berikut :

1. Bagaimanakah pelaksanaan perlindungan hukum terhadap pekerja kontrak dalam pemenuhan jaminan kesehatan dan keselamatan kerja oleh Dinas Linkungan Hidup dan Kebersihan Kota Denpasar?

2. Faktor-faktor apakah yang dapat menghambat pemenuhan hak kesehatan dan keselamatan kerja di Dinas Lingkungan Hidup Dan Kebersihan Kota Denpasar?

\section{ISI}

\subsection{Metodelogi}

\subsubsection{Jenis penelitian}

Jenis penelitian yang digunakan dalam penelitian hukum ini adalah penelitian hukum empiris. Penelitian hukum empiris istilah lain yang digunakan adalah: Penelitian hukum sosioligis dan dapat disebut pula dengan penelitian lapangan, karena bertitik tolak dari data primer, yaitu data yang didapat langsung dari masyarakat sebagai sumber pertama dengan melalui penelitian 
lapangan. ${ }^{3}$ Penelitian lapangan terkait dengan permasalahan ialah dilakukan melalui teknik wawancara.

\subsubsection{Jenis pendekatan}

Penelitian Hukum Empiris umumnya mengenal (7) jenis pendekatan, yaitu: Pendekatan Kasus, Pendekatan PerundangUndangan, Pendekatan Fakta, Pendekatan Analisis Konsep Hukum, Pendekatan Frasa, Pendekatan Sejarah, dan Pendekatan Perbandingan.

Dari 7 Jenis-jenis pendekatan dalam penelitian hukum empiris seperti yang di uraikan di atas, penulis menggunakan jenis Pendekatan Fakta dan Pendekatan Perundang-undangan. Pendekatan fakta adalah pendekatan yang dilakukan dengan melihat langsung kondisi pekerja kontrak pada Dinas Lingkungan Hidup Dan Kebersihan Kota Denpasar. Selain itu, dipergunakan juga pendekatan perundang-undangan adalah pendekatan yang dilakukan dengan menelaah semua undang-undang dan regulasi yang bersangkut paut dengan isu hukum yang telah ditangani ${ }^{4}$. Berkaitan dengan penelitian ini yang dijadikan acuan adalah peraturan perundang-undangan yang berhubungan dengan eksistensi perlindungan hukum terhadap pekerja kontrak pada Dinas Lingkungan Hidup Dan Kebersihan Kota Denpasar.

\subsubsection{Data dan Sumber data}

Adapun data yang digunakan dalam penelitian ini diperoleh dari 2 sumber data, yaitu:

1. Data primer (data lapangan) adalah data yang diperoleh peneliti langsung dari sumber asalnya dan belum diolah dan diuraikan oleh orang lain. ${ }^{5}$ Menurut Peter Mahmud Marzuki, bahan hukum primer ini bersifat otoritatif, artinya mempunyai otoritas, yaitu merupakan hasil tindakan atau 16.

\footnotetext{
${ }^{3}$ Bambang Wahyo, 2008, Penelitian Hukum dalam Praktek, Sinar Grafika, Jakarta, hal.
}

${ }_{5}^{4}$ H. Abdulrah Soejono, 2003, Metode Penelitian Hukum, Rineka Cipta, Jakarta, hal. 56.

${ }^{5}$ Ibid, hal. 25. 
kegiatan yang dilakukan oleh lembaga berwenang untuk permasalahan tersebut. ${ }^{6}$ Data primer ini merupakan data yang diperoleh dari lapangan, yang dalam hal ini data dari hasil penelitian yang dilakukan di Dinas Lingkungan Hidup Dan Kebersihan Kota Denpasar.

2. Data sekunder adalah data yang diperoleh metode library research / penelitian kepustakaan, yaitu penelitian yang dilakukan terhadap dokumen-dokumen resmi, buku-buku, hasil penelitian atau teori-teori para ahli yang berjudul laporan dan seterusnya berhubungan dengan masalah yang dibahas yaitu dengan menggunakan bahan-bahan hukum sebagai berikut:

a. Bahan hukum primer yaitu bahan hukum yang mempunyai otoritas (autoritatif) yang berupa Peraturan PerundangUndangan yaitu sebagai berikut: Undang-undang Dasar Negara Republik Indonesia Tahun 1945 ; Kitab UndangUndang Hukum Perdata ; Undang-Undang Nomor 1 Tahun 1970 Tentang Keselamatan dan; Undang-Undang Nomor 13 Tahun 2003 tentang Ketenagakerjaan ;

b. Bahan hukum sekunder, yang terdiri dari literaturliteratur, buku-buku, makalah, dan jurnal yang ditulis oleh para ahli dan dokumen-dokumen yang berkenaan dengan masalah yang dibahas.

c. Bahan hukum tersier yaitu publikasi tentang hukum yang berupa dokumen yang tidak resmi ataupun bahan hukum sekunder dengan memberikan pemahaman dengan pengetian atas bahan hukum lainnya. Bahan hukum yang dipergunakan adalah Kamus Besar Bahasa Indonesia dan Kamus Hukum.

\footnotetext{
${ }^{6}$ Peter Mahmud Marzuki, 2005, Penelitian Hukum, Prenada Media, Jakarta, hal. 157
} 


\subsubsection{Teknik pengumpulan data}

Penelitian ini menggunakan teknik pengumpulan data tertentu sesuai dengan fakta yang berkaitan dengan permasalahan dalam skripsi ini. Teknik yang digunakan adalah Teknik Wawancara. Wawancara merupakan salah satu teknik yang sering digunakan dalam penelitian hukum empiris. Wawancara bukan sekedar bertanya pada pihak terkait dalam hal ini Dinas Lingkungann Hidup dan Kebersihan Kota Denpasar, wawancara dilakukan memalui pertanyaan-pertanyaan yang dirancang untuk memperoleh jawaban-jawaban yang relevan dan berhubungan dengan masalah objek penelitian yaitu pemenuhan jaminan kesehatan dan keselamatan kerja terhadap pekerja kontrak. Pertanyaan-pertanyaan dirancang agar hasil wawancara nantinya memiliki nilai validitas dan reabilitas.

\subsubsection{Pengolahan dan analisis data}

Proses pengolahan dan analisa data yang digunakan dalam penelitian ini adalah analisis kualitatif, dimana data yang diperoleh tersebut diolah menjadi rangkaian kata-kata yang bersifat monografis atau berwujud kasus-kasus tidak di susun kedalam struktur klasifikasi. Sehingga sampel lebih kepada non probabilitis dan pengumpulan data dengan menggunakan pedoman wawancana dan observasi ke lapangan. Data primer maupun data sekunder yang kemudian di susun secara sistematis.

Penelitian analisis kualitatif atau sering disebut dengan analisis deskriptif kualitatif maka keseluruhan data yang terkumpul baik dari data primer maupun data sekunder akan diolah dan dianalisis dengan cara disusun secara sistematis, digolongkan dalam pola dan thema, diklasifikasikan, dihubungkan antara satu data dengan yang lainnya, dilakukan interpretasi untuk memahami makna data di lapangan serta dilakukan 
penafsiran dari perspektif peneliti setelah memahami keseluruhan kualitas data.

\subsection{Pembahasan}

\subsubsection{Perlindungan Hukum Terhadap Pekererja Kontrak Dalam Menjamin Kesehatan Dan Keselamatan Kerja Oleh Dinas Lingkungan Hidup Dan Kebersihan Kota Denpasar}

Pengertian perlindungan pekerja kontrak (employee protection) adalah perlindungan yang diberikan dalam lingkungan kerja itu sendiri, dengan jalan memberikan tuntunan, maupun dengan jalan meningkatkan pengakuan hak-hak asasi manusia, perlindungan fisik dan teknis serta sosial ekonomi melalui norma yang berlaku7 ${ }^{7}$ Sebagai subjek hukum yang sentral dalam pelaksanaan hubungan industrial adalah pemerintah, penguasa, serta pekerja atau buruh dan serikat pekerja atau serikat buruh. ${ }^{8}$ Secara yurudis hubungan antara pekerja dan pengusaha dalam pelaksanaan hubungan kerja mempunyai kedudukan yang sama. ${ }^{9}$ Sedangkan Pengertian keselamatan kerja adalah keselamatan yang berkaitan dengan mesin, pesawat, alat kerja, bahan dan proses pengolahan, landasan kerja dan lingkungan kerja serta cara-cara melakukan pekerjaan dan proses produksi. Keselamatan kerja merupakan sarana utama untuk mencegah terjadinya kecelakaan kerja yang dapat menimbulkan kerugian berupa luka/cidera, cacat, kematian maupun kerugian harta benda dan

\footnotetext{
${ }^{7}$ Abdul R. Saliman, 2011, Hukum Bisnis Untuk Perusahaan Teori dan Contoh Kasus, Kencana, Jakarta, hal. 274.

${ }^{8}$ Udiana, I Made, 2016, Kedudukan dan Kewenangan Pengadilan Hubungan Insdustrial, Udayana University Press, Denpasar, hal. 42.

${ }^{9}$ Udiana, I Made, 2018, Idustrialisasi dan Tanggung Jawab Pengusaha Terhadap Tenaga Kerja Terlibat Hukum, Udayana University Press, Denpasar, hal. 57.
} 
kerusakan peralatan dan mesin dan kerusakan lingkungan yang secara luas ${ }^{10}$.

Perlindungan terhadap pekerja kontrak dimaksudkan untuk menjamin hak-hak dasar pekerja/buruh dan menjamin kesamaan kesempatan serta perlakuan tanpa adanya diskriminasi atas dasar apapun. Perlindungan tersebut diadakan untuk mewujudkan kesejahteraan pekerja kontrak dan keluarganya dengan tetap memperhatikan perkembangan kemajuan dunia usaha. Salah satu aspek perlindungan dalam ketenagakerjaan yaitu Kesehatan dan Keselamatan Kerja11. Sebagaimana ditegaskan dalam ketentuan Pasal 27 Ayat (2) UUD NRI 1945 yang menyatakan bahwa "tiaptiap warga Negara berhak atas pekerjaan dan penghidupan yang layak bagi kemanusiaan".

Pasal 27 UUD NRI 1945 memberikan dasar perlindungan terhadap pekerja atas suatu pekerjaan yang merupakan hak setiap warga Negara. Pekerjaan identik sebagai sumber penghasilan untuk memenuhi kebutuhan hidup, dapat juga dimaknai sebagai sarana mengaktualisasikan diri sehingga seseorang hidupnya menjadi lebih berharga baik untuk dirinya sendiri maupun bagi orang lain. Kehidupan dan pekerjaan adalah dua sisi dari satu mata uang, agar orang bisa hidup maka orang harus bekerja.

Menurut Soepomo bahwa perlindungan tenaga kerja menjadi dibagi menjadi 3 (tiga) macam, yaitu :

1. Perlindungan ekonomis, yaitu perlindungan tenaga kerja dalam bentuk penghasilan yang cukup, termasuk bila tenaga kerja tidak mampu bekerja diluar kehendaknya.

\footnotetext{
${ }^{10}$ Tarwaka, 2008, Keselamatan dan Kesehatan Kerja Manajemen dan Implementasi K3 di Tempat Kerja, Harapan Press, Surakarta, hal. 4.

${ }^{11}$ Rachmat Trijono, 2014, Pengantar Hukum Ketenagakerjaan, Papas Sinar Sinanti, Jakarta, hal. 53
} 
2. Perlindungan sosial, yaitu perlindungan tenaga kerja dalam bentuk jaminan kesehatan kerja, kebebasan berserikat dan perlindungan hak untuk berorganisasi.

3. Perlindungan teknis, yaitu perlindungan tenaga kerja dalam bentuk keamanan dan keselamatan kerja ${ }^{12}$

Pada saat syarat pertama kali pekerja kontrak diterima kerja maka akan mengacu pada ketentuan dari UU Ketenagakerjaan. Setelah pekerja kontrak diterima bekerja maka kedua belah pihak (pemerintah dan pekerja kontrak) tunduk pada segala ketentuan dari UU Ketenagakerjaan. Pada saat pekerja kontrak mulai diterima bekerja dan saat bekerja maka tidak akan lepas dari hubungannya dengan keselamatan dan kesehatan kerja sesuai dengan ketentuan dari UU No. 1 Tahun 1970. Ketenagakerjaan tersebut sebagaimana diatur oleh UU Ketenagakerjaan yang ada hubungannya terkait dengan ketentuan UU No. 1 Tahun 1970 sangat erat kaitannya dengan Jaminan Sosial Tenaga Kerja. Keterkaitan ini apabila terjadi kecelakaan kerja sebagaimana diatur dalam Undang-undang No. 3 Tahun 1992 Tentang Jaminan Sosial Tenaga Kerja (selanjutnya disebut UU No. 3 Tahun 1992).

Perlindungan pekerja kontrak terkait perlindungan kesehatan dan keselamatan kerja tersebut dimaksudkan agar pekerja kontrak dapat berkerja secara aman dan juga untuk meningkatkan produktivitas. Pasal 86 ayat (1) huruf a UU Ketenagakerjaan merupakan salah satu hak pekerja atau buruh untuk itu pemeritah wajib melaksanakan secara sistematis dan terintergrasi dengan sistem manajemen perusahaan, Dengan terikatnya para pihak dalam perjanjian, maka para pihak harus

${ }^{12}$ Soepomo dalam Abdul Khakim, 2003, Pengantar Hukum Ketenagakerjaan Indonesia, PT. Citra Aditya, Bandung, hal. 61. 
melaksanakan perjanjian yang dibuatnya sudah berlaku seperti undang-undang bagi meraka yang membuatnya ${ }^{13}$.

Keselamatan kerja adalah keselamatan yang bertalian dengan mesin, pesawat alat kerja, bahan dan proses pengolahannya, landasan tempat kerja dan lingkungannya, serta cara-cara melakukan pekerjaan. Obyek keselamatan kerja adalah segala tempat kerja, baik didarat, didalam tanah, dipermukaan air, didalam air maupun di udara. Keselamatan kerja dalam suatu tempat kerja mencakup berbagai aspek yang berkaitan dengan kondisi dan keselamatan sarana produksi, manusia dan cara kerja $^{14}$. Penegasan dan penjelasan dalam penetapan syarat-syarat keselamatan kerja yang harus dipenuhi oleh setiap orang atau badan yang menjalankan usaha, baik formal maupun informal, dimanapun berada dalam upaya memberikan perlindungan keselamatan dan kesehatan semua orang yang berada dilingkungan usahanya sebagaimana dalam UU Nomor 1 Tahun 1970.

UU No. 1 Tahun 1970 bahwa setiap tenaga kerja berhak mendapat perlindungan atas keselamatannya dalam melakukan pekerjaan untuk kesejahteraan hidup dan meningkatkan produksi serta produktivitas Nasional. Setiap pekerja/buruh yang berada di tempat kerja terjamin pula keselamatannya. Setiap sumber produksi perlu dipakai dan dipergunakan secara aman dan efisien. Perlu diadakan segala daya upaya untuk membina norma-norma perlindungan kerja. Pembinaan norma-norma perlu diwujudkan dalam peraturan perundang-undang yang memuat ketentuanketentuan umum tentang keselamatan kerja yang sesuai dengan perkembangan masyarakat.

\footnotetext{
${ }^{13}$ Udiana, I Made,2011, Rekonstruksi Pengaturan Penyelesaian Sengketa Penanaman Modal Asing,Udayana University Press,Denpasar, hal. 10.

14 Soehatman Ramli, 2010, Sistem Manajemen Keselamatan dan Kesehatan Kerja OHSAS18001, Dian Rakyat, Jakarta, hal. 28
} 
Perlindungan terhadap tenaga kerja tidak hanya pada keselamatan kerja namun juga meliputi kesehatan kerja sebagai suatu aspek atau unsur kesehatan yang juga erat kaitannya dengan lingkungan kerja dan pekerjaan, yang secara langsung maupun tidak langsung dapat mempengaruhi efisiensi dan produktivitas kerja. Terdapat pengertian kesehatan kerja adalah bagian dari ilmu kesehatan yang bertujuan agar tenaga kerja memperoleh keadaan kesehatan yang sempurna baik fisik, mental maupun sosial sehingga memungkinkan dapat bekerja secara optimal ${ }^{15}$.

\subsubsection{Faktor Penghambat Pelaksanaan Pemenuhan Jaminan Kesehatan Dan Keselamatan Kerja Kontrak}

Suatu kejadian atau peristiwa tertentu adalah sebab musababnya demikian pula kecelakaan industri/kecelakaan kerja ini. Upaya yang bersifat preventif terhadap pekerja diharapkan dapat mencegah terjadinya kecelakaan kerja. Sedangkan dengan adanya upaya yang bersifat pro aktif diharapkan dapat untuk mendukung jalannya usaha peningkatan keselamatan kerja di tempat kerja. Selanjutnya dengan adanya upaya-upaya yang bersifat represif dapat membuat para pekerja dapat berhati-hati untuk lebih meningkatkan keselamatan kerja.

Menajemen kesehatan dan keselamatan kerja didasarkan kepada Peraturan Kementerian Tenaga Kerja Nomor 5 Tahun 1996 tentang Tentang Sistem Manajemen Keselamatan Dan Kesehatan Kerja sebagaimana diatur pada ketentuan Pasal 1 ayat (1) yang menyebutkan bahwa "Sistem Manajemen kesehatan dan keselamatan kerja dilingkungan kerja adalah bagian dari sistem manajemen secara keseluruhan yang meliputi struktur organisasi, perencanaan, tanggung jawab, pelaksanaan, prosedur, proses dan

${ }^{15}$ Lalu Husni, 2004, Hukum Ketenagakerjaan Indonesia, Rajawali Press, Jakarta, hal. 140 
sumber daya yang dibutuhkan bagi pengembangan, penerapan, pencapaian, pengkajian dan pemeliharaan kebijakan keselamatan dan kesehatan kerja dalam rangka pengendalian resiko yang berkaitan dengan kegiatan kerja guna terciptanya tempat kerja yang aman, efisien dan produktif".

Penegakan atau penerapan peraturan perundang-undangan yang merupakan upaya untuk menjaga keseimbangan antara hak dan kewajiban dapat dilaksanakan dengan baik, dan difokuskan untuk mengurangi terjadinya kecelakaan kerja di tempat kerja. Sebab dasar atau asal mula terjadinya kecelakaan kerja pastilah terlihat dari sebab dasar yang menjadikan terjadinya peristiwa kecelakaan kerja yang dapat dilihat dari faktor yaitu Komitmen atau partisipasi dari pihak manajemen atau pimpinan perusahaan dalam upaya penerapan Keselamatan dan Kesehatan Kerja di perusahaannya, faktor manusia atau para pekerjanya sendiri, dan kondisi tempat kerja, sarana kerja dan lingkungan kerja. Selain sebab dasar juga terdapat penyebab utama dari adanya kejadian kecelakaan kerja yaitu adanya faktor dan persyaratan keselamatan dan kesehatan kerja yang belum dilaksanakan secara benar (Substandards). Sebab utama kecelakaan kerja meliputi faktor:

a) Faktor manusia atau adanya tindakan tidak aman (unsafeaction). Dilatar belakangi oleh adanya tindakan berbahaya dari tenaga kerja bisa terjadi karena: Kurang pengetahuan dan ketrampilan kerja (lack of knowledge and skill); Ketidakmampuan bekerja secara normal (inadequate capability) ; Ketidakfungsian tubuh karena cacat yang tidak nampak (bodily defect) ; Kelelahan dan kejenuhan (fatique and boredom) ; Sikap dan tingkah laku yang tidak aman (unsafe attitude and habits); Kebingungan dan stress karena prosedur kerja yang baru dan belum dapat dipahami (confuse and stress) ; Belum menguasai atau belum trampil 
dengan peralatan atau mesin baru (lack of skill) ; Penurunan konsentrasi dari tenaga kerja saat melakukan pekerjaan (difficulty in concentrating) ; Sikap masa bodoh dari tenaga kerja (ignorance) ; Kurangnya motivasi kerja dari tenaga kerja (improper motivation) ; Kurangnya kepuasan kerja (low job satisfaction) dan Sikap kecenderungan mencelakai diri sendiri, dan sebagainya.

b) Faktor lingkungan atau kondisi tidak aman (unsafe condition). Lingkungan disini diartikan bahwa kecelakaan kerja terjadi apabila lingkungan fisik (mesin, peralatan, pesawat, bahan, lingkungan dan tempat kerja, proses kerja sifat pekerjaan dan sistem kerja) dan faktor-faktor yang berkaitan dengan penyediaan fasilitas, pengalaman manusia yang dapat menyebabkan kecelakaan kerja.

c) Interaksi manusia dan sarana pendukung kerja. Apabila interaksi dan sarana pendukung kerja tidak berjalan dengan sesuai maka akan terjadi kecelakaan kerja. Dengan demikian, penyediaan sarana kerja yang sesuai dengan kemampuan, kebolehan dan keterbatasan manusia harus sudah dilaksanakan sejak perencanaan ${ }^{16}$.

\section{PENUTUP}

\subsection{Kesimpulan}

Berdasarkan rumusan masalah dan kajian-kajian diatas, maka dapat disimpulkan hal-hal sebagai berikut :

1. Pelaksanaan jaminan keselamatan dan kesehatan kerja pekerja kontrak dimaksudkan untuk menjamin hak-hak dasar pekerja/buruh dan menjamin kesamaan kesempatan serta perlakuan tanpa adanya diskriminasi atas dasar

16 Tarwaka, 2008, Keselamatan dan Kesehatan Kerja Manajemen dan Implementasi K3 di Tempat Kerja, Harapan Press, Surakarta, hal. 89 
apapun melalui pembinaan, peningkatan, penanggulangan keselamatan dan kesehatan kerja yang dilakukan dengan memberikan pelindung kepala, pelindung mata dan muka, pelindung telinga, pelindung pernapasan beserta perlengkapannya, pelindung tangan; dan/atau pelindung kaki sesuai dengan Standar Nasional Indonesia (SNI) atau standar yang berlaku serta dilakukan dengan pola mendaftarkan dan memberikan kartu BPJS ketenagakerjaan dan kartu BPJS kesehatan.

2. Faktor penghambat pelaksanaan pemenuhan jaminan keselamatan dan kesehatan kerja kepada pekerja kontrak dikarenakan adanya tindakan tidak aman yang dilatarbelakangi oleh adanya tindakan berbahaya dari pekerja bisa terjadi karena kurangnya pengetahuan dan ketrampilan kerja, kurangnya menguasai atau belum trampil dengan peralatan atau mesin baru dan faktor alamiah yaitu kondisi lingkungan yang sangat dekat dengan bahan, cairan, kotoran dan zat berbahaya yang dapat menyebabkan dan menularkan penyakit kepada para pekerja tidak dapat dihindarkan yang didukung pula dengan prilaku tenaga kerja yang tidak taat terhadap prinsip ketentuan yang sebenarnya ditujukan untuk melindungi pekerja dari resiko dan bahaya dalam melakukan pekerjaannya.

\subsection{Saran}

Berdasarkan uraian pemasalahan, hasil kajian dan kesimpulan, maka dapat disarankan hal-hal sebagai berikut :

1. Disarankan kepada Dinas Lingkungan Hidup Dan Kebersihan Kota Denpasar untuk tetap meberikan pemahaman secara terus menerus sehingga kelalaian dari tenaga kerja kontrak tetap dapat dihindarkan, selain itu 
pemberian fasilitas dan mendaftarkan seluruh pekerja kontrak tanpa terkecuali melalui pemberian kartu BPJS ketenagakerjaan dan kartu BPJS kesehatan sehingga perlindungan dapat dilakukan secara pre-emtif dan prefentif bahkan represif.

2. Disarankan kepada pekerja kontrak untuk selalu mengikuti segala bentuk ketentuan sesuai dengan standar yang telah ditetapkan pemerintah meskipun akan dirasakan sebagai penghalang dan penghambat keefisienan kerja seperti menggunakan perlengkapan secara lengkap yang memang akan bertolakbelakang dengan kebiasaan kerja sebelumnya, namun hal tersebut diatur oleh pemerintah melalui suatu aturan ditujukan untuk memberikan rasa aman dan keselamatan sehingga kesehatan kerja dapat dijaga untuk tetap dapat berkerja secara efektif dan efisien melaksanakan hak dan kewajiban sebagai pekerja Dinas Lingkungan Hidup Dan Kebersihan Kota Denpasar sebagaimana ditentukan dalam perundang-undangan.

\section{DAFTAR PUSTAKA}

Abdul R. Saliman, 2011, Hukum Bisnis Untuk Perusahaan Teori dan Contoh Kasus, Kencana, Jakarta

Bambang Wahyo, 2008, Penelitian Hukum dalam Praktek, Sinar Grafika, Jakarta

H. Abdulrah Soejono, 2003, Metode Penelitian Hukum, Rineka Cipta, Jakarta

Indrajit dan Djokopranoto, 2006, Proses Bisnis: Outsourcing, PT. Grasindo, Jakarta,

Lalu Husni, 2004, Hukum Ketenagakerjaan Indonesia, Rajawali Press, Jakarta

N.L.M. Mahendrawati, 2009, "Perjanjian Outsourcing Dalam Kegiatan Bisnis", Kertha Wicaksana, Vol.15. No 2, hal. 151 URL: https://docobook.com/perlindungan-hukum-terhadaptenaga-kerja-outsourcing-ojs-unu.html diakses pada 3 Januari 2018.

Peter Mahmud Marzuki, 2005, Penelitian Hukum, Prenada Media, Jakarta 
Rachmat Trijono, 2014, Pengantar Hukum Ketenagakerjaan, Papas Sinar Sinanti, Jakarta

Udiana, I Made, 2016, Kedudukan dan Kewenangan Pengadilan Hubungan Insdustrial, Udayana University Press, Denpasar, hal.42.

Udiana, I Made, 2018, Industrialisasi dan Tanggung Jawab Pengusaha Terhadap Tenaga Kerja Terlibat Hukum, Udayana University Press, Denpasar, hal. 57.

Udiana, I Made, 2011, Rekontruksi Pengaturan Penyelesaian sengketa Penanaman modal Asing, Udayana University Press, Denpasar, hal. 10

Soehatman Ramli, 2010, Sistem Manajemen Keselamatan dan Kesehatan Kerja OHSAS18001, Dian Rakyat, Jakarta, hal. 28

Soepomo dalam Abdul Khakim, 2003, Pengantar Hukum Ketenagakerjaan Indonesia, PT. Citra Aditya, Bandung

Tarwaka, 2008, Keselamatan dan Kesehatan Kerja Manajemen dan Implementasi K3 di Tempat Kerja, Harapan Press, Surakarta 